\title{
Results of the Toxoplasmosis Screening in 9311 Pregnant Women in a Tertiary Center in Turkey
}

\section{Türkiye'de Üçüncü Basamak Bir Merkezde Yapılan 9311 Gebede Toksoplazma Taramasının Sonuçları}

\author{
Özgür KOÇAK'(IID), Özgür KAN'(IiD) \\ ${ }^{1}$ Department of Gynecology and Obstetrics, Faculty of Medicine, Hitit University, Çorum, Turkey \\ Cite this article as: Koçak Ö, Kan Ö. Results of the toxoplasmosis screening in 9311 pregnant women in a tertiary center in Turkey.
} FLORA 2020;25(3):332-8.

\begin{abstract}
Introduction: Toxoplasma gondii is an important parasite that can cause permanent sequelae to the fetus when infected during pregnancy in humans. Although the frequency of this parasite varies widely between countries, it is known that it is common in our country. The aim of this study was to determine the seroprevalence of toxoplasma in pregnant women admitted to a tertiary hospital in central Anatolia and to evaluate the pregnancy outcomes together with seroprevalence.

Materials and Methods: A total of 9311 patients admitted to a tertiary hospital between January 2016 and December 2018 were included into the study. After serological examination, avidity test was performed in cases suggestive of acute infection. Amniocentesis was recommended to be performed by Polimeraze Chain Reaction $(P C R)$ in patients with low avidity.

Results: The frequency of Toxoplasma immunoglobulin (Ig) G and M seropositivity rates were $20.3 \%$ and $0.28 \%$, respectively. Low avidity was found in approximately $27 \%$ of the patients with IgM positivity, and only $15.4 \%$ had low avidity by confirmatory test. One patient could not be reached during follow-up. PCR was performed in 4 patients whose low avidity value was confirmed by re-tests and all of their PCR results were reported negative. No cases of congenital toxoplasmosis were detected during the 3 years in our clinic.

Conclusion: The inclusion of toxoplasma in routine screening programme is still controversial and differs between countries. Screening in areas with a high rate of toxoplasma, such as in our country, may be rational. If infection is detected, treatment may be recommended because it may reduce the transmission to the fetus.
\end{abstract}

Key Words: Toxoplasma; Screening; Pregnancy; Antenatal; Turkey 


\title{
Öz
}

\section{Türkiye'de Üçüncü Basamak Bir Merkezde Yapılan 9311 Gebede Toksoplazma Taramasının Sonuçları}

\begin{abstract}
Özgür KOÇAK', Özgür KAN ${ }^{1}$
${ }^{1}$ Hitit Üniversitesi, Kadın Hastalıkları ve Dog̃um Anabilim Dalı, Çorum, Türkiye

Giriş: Toksoplazma gondi, insanlarda hamilelik sırasında infekte olduğunda fetusa kalıcı sekellere neden olabilecek önemli bir parazittir. Bu parazitin sıklığı ülkeler arasında büyük farklııklar gösterse de ülkemizde yaygın olduğu bilinmektedir. Bu çalışmanın amacı, Orta Anadolu'daki tersiyer merkez hastaneye başvuran gebe kadınlarda toksoplazmanın seroprevalansını belirlemek ve gebelik sonuçlarını seroprevalansı ile birlikte değerlendirmektir.
\end{abstract}

Materyal ve Metod: Çalışmaya Ocak 2016-Aralık 2018 tarihleri arasında hastaneye başvuran toplam 9311 hasta alındı. Serolojik incelemeden sonra akut infeksiyonu düşündüren olgulara avidite testi yapıldı. Düşük avidite saptananlarda Polimeraz Zincir Reaksiyonu $(P C R)$ yapılması için amniyosentez önerildi.

Bulgular: Toksoplazma immünglobulin (Ig) G ve M seropozitiflik sıklı̆ı sırasıyla \%20.3 ve \%0.28 idi. IgM pozitifliği olan hastaların yaklaşık \%27'sinde düşük avidite bulunmuştur ve doğrulama testiyle sadece \%15.4'ünde düşük avidite saptanmıştır. Düşük avidite değeri tekrar testlerle doğrulanan 4 hastaya PCR yapıldı ve tüm PCR sonuçları negatif olarak bildirildi. Kliniğimizde 3 yıl boyunca hiçbir hastada konjenital toksoplazmoz olgusu saptanmadı.

Sonuç: Rutin tarama programına toksoplazmanın dahil edilmesi halen tartısmalıdır ve ülkeler arasında farklılı göstermektedir. Ülkemizde olduğu gibi yüksek oranda toksoplazma bulunan bölgelerde tarama yapılması rasyonel olabilir. Infeksiyon tespit edilirse, fetusa geçişi azaltabileceğinden tedavi önerilebilir.

Anahtar Kelimeler: Toksoplazma; Tarama; Gebelik; Antenatal; Türkiye

\section{INTRODUCTION}

Toxoplasma gondii is a protozoan parasite generating a parasitic disease "toxoplasmosis" in humans and in animals ${ }^{[1]}$. In adults, toxoplasmosis may be asymptomatic ${ }^{[2]}$. If symptomatic, the only symptoms may be flu-like; headache, muscle aches, etc. The infection is usually acquired during adolescence and childhood ${ }^{[3]}$. It may cause serious problems if infection occurs during pregnancy and if transmitted to the fetus. In this case, it is called congenital toxoplasmosis, and the incidence of infection during pregnancy ranges from 1-8 per 1000 pregnancies ${ }^{[4]}$. Fetal infection occurs with the transmission of the parasite through the placenta $^{[5]}$. Gestational week of the pregnancy impact the clinical features. Intracranial calcifications, hydrocephalus, echogenic bowel, hepatomegaly, splenomegaly, intrahepatic calcifications, intrauterine growth restriction, ascites, pericardial and/or pleural effusions, hydrops fetalis, fetal demise, placental densities may be the sonographic findings of congenital toxoplasmosis ${ }^{[6]}$. All infections, even all fetal findings, do not lead to serious sequelae. For that reason, it is very important for clinicians to detect the infected pregnant woman.

The aim of this study was to retrospectively evaluate the Toxoplasma IgG and IgM positive pregnant woman, and thus to determine the seroprevalence and detect the postnatal results of these pregnancies in a tertiary center.

\section{MATERIALS AND METHODS}

This is a retrospective study, and all the data were obtained from the hospital database, records, and if necessary, by phone calls. The study was conducted at a tertiary center. Approval of the local ethics committee was received before the study started (Date: April, 25, 2019; No: 2019-145). Female patients who applied for pregnancy follow-up in our obstetrics outpatient clinic between January 2016 and December 2018 were included into this study.

A total of 9311 women with proved intrauterine pregnancy by ultrasound at the first trimester were included into this study. Demographical features including age, obstetrical history 
and comorbidities at the first prenatal visit were reviewed from patient files.

Toxoplasma IgG and/or IgM antibodies were tested according to the clinician's prediction or the women's complaints during pregnancy follow-up. Generally, Toxoplasma tests are performed when the intrauterine pregnancy is proven, and it is generally done at the first visit in the first trimester.

Toxoplasma IgG and Toxoplasma IgM were analyzed using Cobas 6000 diagnostic system (Roche Diagnostics Ltd, Switzerland) according to the manufacturer's instructions. The Elecsys Toxo IgM and IgG assay was used for the quantitative determination of specific antibodies to toxoplasmosis in human serum or plasma samples. The tests were performed on the Cobas 6000 Analyzer. According to the manufacturer's instructions, values of $\operatorname{IgG}$ and IgM levels greater than $3 \mathrm{IU} /$ $\mathrm{mL}$ and $1 \mathrm{IU} / \mathrm{mL}$ were regarded as positive, respectively. Pregnant woman who had high levels of Toxoplasma IgG and IgM levels were tested with avidity test to determine acute or chronic infection.

While avidity index greater than 0.300 for Toxoplasma IgG was regarded as high avidity, less than 0.200 was regarded as low avidity. Low avidity may be an indicator of acute infection. All positive test results were controlled and retested by the same way. Values between 0.200 and 0.300 were considered as intermediate values, and further investigations were made. Further investigations were done by Polymerase chain reaction $(\mathrm{PCR})$ which is one of the basic tests of modern molecular biology. One DNA molecule can be reproduced millions of times and quickly diagnosed by PCR.

Statistical Package for the Social Sciences (SPSS) version 22.0 was used for statistical calculations. Data were presented with the number of pregnant women and percentage and defined by median (minimum-maximum). Numbers and percentages were used as descriptive statistical methods in evaluating the data.

\section{RESULTS}

Totally, 9311 pregnant women were included into this study. Median age of the population was 25 years (range: 16-47 years). Toxoplasma IgG positivity frequency varied between $18.5 \%$ and $24.5 \%$ by the years, and 3 years average IgG positivity was 20.3\% (Table 1).

Toxoplasma IgM seropositivity ranged between $0.26 \%$ and $0.35 \%$. Three years average IgM seropositivity was $0.28 \%$ (Table 2).

Avidity test was performed in all 26 women who had IgM positivity. Low avidity was detected in seven of those 26 women. Spiramycin was started empirically in those seven women with low avidity. Avidity was checked with the same laboratory two weeks later. One woman was lost to follow up during the procedure. Two weeks

Table 1. Toxoplasma IgG seropositivity by years

\begin{tabular}{lcc} 
Years & Total test & Toxoplasma IgG (+) $\mathbf{n}(\%)$ \\
\hline 2016 & 1716 & $421(24.5 \%)$ \\
2017 & 2787 & $518(18.5 \%)$ \\
2018 & 3542 & $693(19.6 \%)$ \\
Total & 8045 & $1632(20.3 \%)$
\end{tabular}

Table 2. Toxoplasma IgM seropositivity by years

\begin{tabular}{lcc} 
Years & Total test & Toxoplasma IgM (+) $\mathbf{n}(\%)$ \\
\hline 2016 & 1953 & $7(0.35 \%)$ \\
2017 & 3080 & $8(0.26 \%)$ \\
2018 & 4278 & $11(0.33 \%)$ \\
Total & 9311 & $26(0.28 \%)$
\end{tabular}




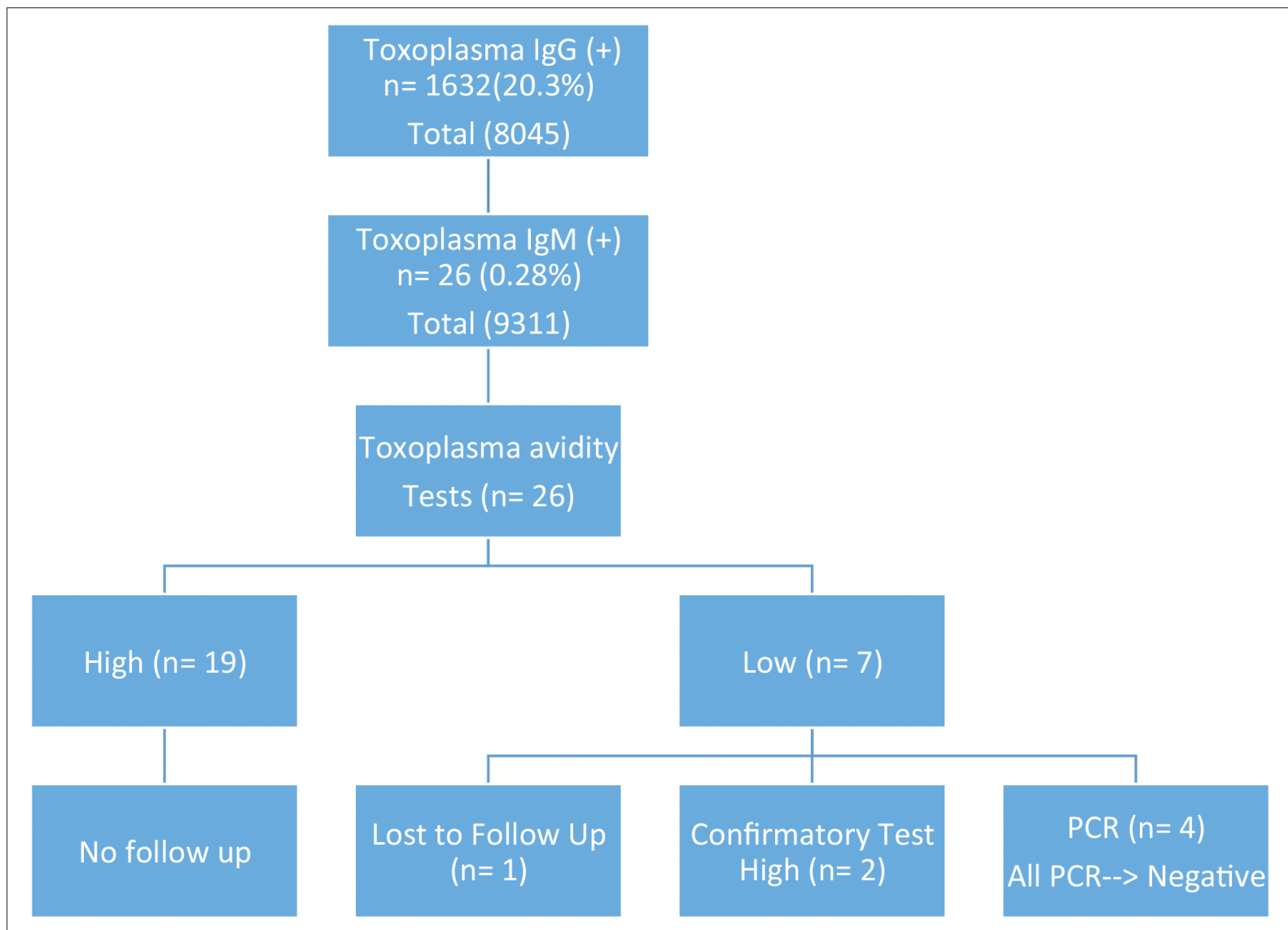

Figure 1. The flow chart of the cases.

later, the avidity test of two women was found to be high in repeated test. Four women with low avidity test underwent PCR after amniocentesis. All women had negative PCR results.

Congenital toxoplasmosis has a triad that consists of intracranial calcifications, chorioretinitis and hydrocephalus. No fetus was detected with this triad at birth. Congenital toxoplasmosis may not show any clinical manifestations on routine physical examination. For that reason, these suspected four fetuses were detailed in central nervous system (CNS) imaging and ophthalmologic examination. At the end of these examinations, no pathologic findings were detected. These fetuses were followed up to 6 months to three years, and no congenital toxoplasmosis was detected in any fetus during the follow up.

\section{DISCUSSION}

$T$. gondii seroprevalence among childbearing-aged women (aged between 15-45 years) has a range of $8.2 \%-63.2 \%$ in Europe $e^{[7]}$. In the United States of America, it is $6.2 \%{ }^{[8]}$. The seroprevalence of $T$. gondii has decreased over the past 20 years ${ }^{[8]}$. Toxoplasmosis infection may cause serious complications if occurs during pregnancy ${ }^{[9]}$.

Fetal infection risk increases steeply with gestational age. A meta-analysis has shown that seroconversion rate is $15 \%$ at 13 weeks, $44 \%$ at 26 weeks and at 36 week, it is as high as $71 \%[10]$. Although fetal infection risk increases by gestational age, the risk of clinical sequelae decreases.

The need for routine screening of all pregnant women for toxoplasmosis is controversial because maternal infection during pregnancy is as low as $1-8$ to 1000 in $\mathrm{UK}^{[4]}$. For this reason, some countries such as the United States, United Kingdom, Canada and some parts of Europe are against screeening ${ }^{[11-13]}$. On the other hand, some 
countries in Europe, where seroprevalence is higher, perform screening as routine follow up ${ }^{[14,15]}$ Even some studies recommend screening for congenital toxoplasmosis monthly, bimonthly or with three months intervals ${ }^{[12,15]}$.

It is mentioned that some countries are against screening but if there is high clinical suspicion of acute toxoplasmosis infection during pregnancy, diagnostic tests should be performed ${ }^{[6]}$. These high clinical manifestations are fever and adenopathy in woman and intracranial calcification and ventricular dilatation of the fetus.

A review in 2019 investigating toxoplasmosis in Turkey reported that toxoplasmosis seropositivity rate was one third of the population ${ }^{[16]}$.

In our country, the Ministry of Health has no specific policy regarding toxoplasmosis screening during pregnancy. There is no sentence about toxoplasma in the prenatal care management guide published in 2014 by Ministry of Health of Turkey ${ }^{[17]}$. Turkish Perinatology Society does not recommended testing for toxoplasma serology $\mathrm{du}^{-}$ ring pregnancy. Therefore, every clinician's approach to toxoplasma is different according to their own knowledge and experience in our country.

In our study, we examined more than 9.000 pregnant women and we found the Toxoplasma IgG positivity rate as $20.3 \%$ and IgM positivity rate as $0.28 \%$ in mid-northern region of Turkey. Ocak et al. have reported anti-Toxoplasma IgG antibody as $52.1 \%$ and anti-Toxoplasma IgM antibody as $0.54 \%$ in southern Turkey ${ }^{[18]}$. Harma et al. have found Toxoplasma IgG positivity as $60.4 \%$ and IgM positivity as $3 \%$ in a city in Southeastern Turkey ${ }^{[19]}$. These studies were reported in 2004 and 2009. The prevalence of higher IgM positivity rates in these studies may be due to the year they were published. As mentioned before, toxoplasma IgG and IgM positivity rate has decreased in the past decades due to training, compliance rules of hygiene, and raising awareness ${ }^{[8]}$. This may be the case in Turkey ${ }^{[20]}$.

In this study, 9311 pregnant women in total were tested, and $\mathrm{IgM}$ positivity was detected in 26 of them $(0.28 \%)$. In these women, IgG was also positive. If a woman has both IgM positivity and IgG positivity, Hedman et al. first described
IgG avidity test in 1989 in such cases. In this test, high avidity excludes recent infection and low avidity suggests the contrary ${ }^{[21]}$. The detection of recently infected pregnant women is very crucial due to transmission rates. In a meta-analysis, transmission rate has been confirmed as $15 \%$ at 13 weeks, $44 \%$ at 26 weeks, and $71 \%$ at 36 weeks $^{[10]}$. Although transmission rate increases as the gestational week increases, the sequelae rate decreases. In one study, it has been shown that sequelae rate decreases by approximately 4\% at every week ${ }^{[6]}$. As the gestational week will play an important role in fetal infection, factors such as parasite load, strain of the parasite, and mother's immune system play a role in transmission $^{[6]}$.

In a paper reported by Peyron et al., transmission rate has been reported to be about half in women treated three weeks after infection detection compared to the women treated eight weeks after infection ${ }^{[22]}$. Some other studies have also shown that early treatment of toxoplasmosis lowers transmission rates and the sequelae $e^{[23,24]}$.

In this study, 26 women who were positive for Toxoplasma IgM were recommended to undergo avidity testing. Spiramycin treatment was started empirically to the women with positive toxoplasma IgM. Treatment was discontinued in women with high avidity test and continued with low avidity. Avidity test revealed low in seven women.

Avidity test is used to determine when antibodies are formed ${ }^{[25]}$. If the avidity is high, the infection is thought to have occurred before four months ${ }^{[26]}$. The benefit of low avidity in clinical use is less than high avidity because there are many causes of low avidity. In some cases, low avidity can be detected during months, which creates a dilemma in which gestational infection is occurred. Therefore, looking at low avidity test can be misleading to conclude that there is an acute infection without confirmatory tests ${ }^{[27]}$. In these situations, agglutination assays and/or specific immunoglobulin tests may be used ${ }^{[28]}$.

In this study, 26 women who were positive for Toxoplasma IgM were recommended to undergo avidity testing. Avidity test revealed low avidity in seven women that may indicate acute 
infection. The avidity test was repeated in six women because one of them missed the follow up, and test results of two of the six women reported high avidity.

If toxoplasmosis is clinically suspicious, amniocentesis and PCR are recommended after 18 weeks to show $T$. gondii DNA in the amniotic fluid $^{[29]}$. In a systematic review, the specificity of PCR in amniotic fluid has been detected as $98 \%$ and sensitivity as approximately $74 \%$ in all trimesters $^{[29]}$.

However, the most important factor affecting the sensitivity of PCR is the time from the onset of infection. It is known that the virus will reach the amniotic fluid after a certain time of infection. Therefore, Toxoplasma DNA cannot always be detected by PCR in every infected women. For this reason, congenital toxoplasmosis diagnosis is based on clinical suspicion and confirmation with the laboratory.

In our study, PCR was performed in four women and all of them were reported as negative.

There is no randomized controlled trial showing that toxoplasmosis treatment during pregnancy improves pregnancy outcomes. However, prenatal treatment is offered to reduce the risk of possible congenital toxoplasmosis ${ }^{[10]}$.

There are two treatment options that reduce congenital toxoplasmosis; spiramycin and pyrimethamine-sulfadiazine plus folinic acid. If the women are < 18 weeks of gestation at the time of diagnosis, spiramycin is the first choice, otherwise pyrimethamine-sulfadiazine plus folinic acid is the choice.

In this study, spiramycin was started in seven women with suspected acute toxoplasma infection and no newborn congenital toxoplasmosis was detected. It has a triad that consists of intracranial calcifications, chorioretinitis and hydrocephalus. However, < 10 percent of cases has this triad at birth $^{[30]}$. Congenital toxoplasma was not detected in all of these women's babies.

In conclusion, trends in toxoplasmosis screening are different between countries. It is included in routine screening program in countries with high positivity rates such as France. It can be said that positivity rate is high in our country. Therefore, we think that routine screening will be beneficial and cost effective.

\section{ETHICS COMMITTEE APPROVAL}

Ethics committee approval was obtained for this study from of Hitit University Non-Invasive Research Ethical Committee (Decision No: 2019145 Date: 26.04.2019)

\section{CONFLICT of INTEREST}

The authors declare that they have no conflict of interest.

\section{AUTHORSHIP CONTRIBUTIONS}

Concept/Design: ÖK, ÖK

Analysis/Interpretation: ÖK, ÖK

Data Acquisition: ÖK, ÖK

Writting: ÖK, ÖK

Final Approval: ÖK, ÖK

\section{REFERENCES}

1. Centers for Disease Control and Prevention (CDC). Parasites - Toxoplasmosis (Toxoplasma infection) Erişim tarihi: 23 Ağustos 2015. Available from: https://www.cdc.gov/ parasites/toxoplasmosis/epi.html

2. Hunter $C A$, Sibley $L D$ : Modulation of innate immunity by Toxoplasma gondii virulence effectors. Nat Rev Microbiol 2012;10:766.

3. Welton NJ, Ades AE. A model of toxoplasmosis incidence in the UK: Evidence synthesis and consistency of evidence. JRSS-C Applied Statistics 2005; 54:385

4. Gilbert RE, Peckham CS. Congenital toxoplasmosis in the United Kingdom: to screen or not to screen? I Med Screen 2002;9:135-41.

5. Remington JS MR, Thulliez P, Desmonts G. Toxoplasmosis. In: Remington KJ, Wilson CB, Baker CJ (eds). Infectious disease of the fetus and newborn infant. $6^{\text {th }}$ ed. Philadelphia: Elsevier Saunders, 2006:947.

6. Maldonado YA, Read JS. Diagnosis, Treatment, and Prevention of Congenital Toxoplasmosis in the United States. Pediatrics 2017;139:e20163860

7. Pappas G, Roussos N, Falagas ME. Toxoplasmosis snapshots: global status of Toxoplasma gondii seroprevalence and implications for pregnancy and congenital toxoplasmosis. Int J Parasitol 2009;39:1385-94.

8. Jones JL, Kruszon-Moran D, Rivera HN, Price C, Wilkins PP. Toxoplasma gondii seroprevalence in the United States 2009-2010 and comparison with the past two decades. Am I Trop Med Hyg 2014;90:1135-9. 
9. Hohlfeld P, Daffos F, Thulliez P, Aufrant C, Couvreur I, MacAleese J, et al: Fetal toxoplasmosis: outcome of pregnancy and infant follow-up after in utero treatment. J Pediatr 1989;115):765-9.

10. Thiebaut R, Leproust S, Chene G, Gilbert R. Effectiveness of prenatal treatment for congenital toxoplasmosis: a meta-analysis of individual patients' data. Lancet 2007;369:11522.

11. Stein IF, Leventhal ML. Amenorrhea associated with bilateral polycy-stic ovaries. Am J Obstet Gynecol 1935;29:18191.

12. Paquet C, Yudin MH. Toxoplasmosis in pregnancy: prevention, screening, and treatment. J Obstet Gynaecol Can 2018;40:e687-93.

13. Practice bulletin no. 151: Cytomegalovirus, parvovirus B19, varicella zoster, and toxoplasmosis in pregnancy. Obstet and Gynecol 2015; 125:1510-25.

14. Gilbert R, Gras L. Effect of timing and type of treatment on the risk of mother to child transmission of Toxoplasma gondii. BJOG 2003;110:112-20.

15. Wallon M, Peyron F, Cornu C, Vinault S, Abrahamowicz M, Kopp $C B$, et al. Congenital toxoplasma infection: monthly prenatal screening decreases transmission rate and improves clinical outcome at age 3 years. Clin Infect Dis 2013;56(9):1223-31.

16. Koloren Z, Dubey JP. A review of toxoplasmosis in humans and animals in Turkey. Parasitology 2019;147:1-17.

17. Prenatal Care Management Guide, 2014.

18. Ocak S, Zeteroglu S, Ozer C, Dolapcioglu K, Gungoren A. Seroprevalence of Toxoplasma gondii, rubella and cytomegalovirus among pregnant women in southern Turkey. Scandinavian J Infect Dis 2007;39:231-4.

19. Harma M, Harma M, Gungen N, Demir N. Toxoplasmosis in pregnant women in Sanliurfa, Southeastern Anatolia City, Turkey. J Egypt Soc Parasitol 2004;34:519-25.

20. Inci M, Yağmur G, Aksebzeci T, Kaya E, Yazar S. Kayseri'de kadınlarda Toxoplasma gondii seropozitifliğinin araştırılması. Türkiye Parazitol Derg 2009;33:191-4.

21. Hedman K, Lappalainen M, Seppäiä I, Mäkelä O. Recent primary toxoplasma infection indicated by a low avidity of specific IgG. J Infect Dis 1989;159:736-40.
22. Peyron F, Mc Leod R, Ajzenberg D, Contopoulos-loannidis $D$, Kieffer $F$, Mandelbrot $L$, et al. Congenital toxoplasmosis in France and the United States: One Parasite, Two Diverging Approaches. PLoS Negl Trop Dis 2017;11:e0005222.

23. Sickinger E, Gay-Andrieu F, Jonas G, Schultess J, Stieler M, Smith $D$, et al. Performance characteristics of the new ARCHITECT toxo IgG and Toxo IgG avidity assays. Diagn Microbiol Infect Dis 2008;62(3):235-44.

24. Jost C, Touafek F, Fekkar A, Courtin R, Ribeiro M, Mazier D, et al. Utility of Immunoblotting for early diagnosis of toxoplasmosis seroconversion in pregnant women. Clin Vaccine Immunol 2011;18:1908-12.

25. Bobic B, Klun I, Vujanic $M$, Nikolic A, Ivovic V, Zivkovic $T$, et al. Comparative evaluation of three commercial Toxoplasma-specific IgG antibody avidity tests and significance in different clinical settings. J Med Microbiol 2009;58:358-64.

26. Beghetto E, Buffolano W, Spadoni A, Del Pezzo M, Di Cristina $M$, Minenkova $O$, et al. Use of an immunoglobulin $G$ avidity assay based on recombinant antigens for diagnosis of primary Toxoplasma gondii infection during pregnancy. I Clin Microbiol 2003;41(12):5414-8.

27. Villard O, Breit L, Cimon B, Franck J, Fricker-Hidalgo H, Godineau $N$, et al. Comparison of four commercially available avidity tests for Toxoplasma gondii-specific lgG antibodies. Clin Vaccine Immunol 2013;20:197-204.

28. Robert-Gangneux F, Darde ML. Epidemiology of and diagnostic strategies for toxoplasmosis. Clin Microbiol Rev 2012;25:264-96.

29. de Oliveira Azevedo CT, do Brasil PE, Guida L, Lopes Moreira ME. Performance of polymerase chain reaction analysis of the amniotic fluid of pregnant women for diagnosis of congenital toxoplasmosis: A systematic review and meta- $a$ nalysis. PloS ONE 2016;11:e0149938.

30. Tamma P. Toxoplasmosis. Pediatr Rev 2007;28:470-1.

\section{Address for Correspondence/Yazıșma Adresi}

Dr. Öğr. Üyesi Özgür KOÇAK

Hitit U̇niversitesi Tıp Fakütesi,

Kadın Hastalıkları ve Doğum Anabilim Dalı,

Corum-Türkiye

E-mail: dr.ozgur@hotmail.com 